\title{
Discussion on Tuition of Higher Vocational Education in Viet Nam
}

\author{
Phan Anh Tuan \\ School of Humanities \& Social Science, University of Science and Technology Beijing, Beijing City, China
}

\section{Email address:}

fananhtuan@yahoo.com

\section{To cite this article:}

Phan Anh Tuan. Discussion on Tuition of Higher Vocational Education in Viet Nam. Science Journal of Education. Vol. 5, No. 1, 2017, pp. 24-27. doi: 10.11648/j.sjedu.20170501.15

Received: January 27, 2017; Accepted: February 16, 2017; Published: March 2, 2017

\begin{abstract}
Price and solvency are two basic attributes to constitute tuition standards of a training program. However, the tuition of higher vocational education in Vietnam in recent years is low with slow growth, exceeds the affordability of students, especially for those who have a difficult economic situation. Based on statistical analysis of the tuition of higher vocational education during 2010 - 2015, this article has detected the internal contradictions as well as the limitations on the tuition of higher vocational education in Viet Nam due to the direct impact from the increase in excess of CPI, GDP per capita is slow and the student loan program is limited. Thereby, this article has suggested a number of suitable recommendations and solutions. Hopefully, these solutions are practically useful to perfect the tuition of higher vocational education in Viet Nam nowadays.
\end{abstract}

Keywords: Viet Nam, Tuition, Price, Solvency, The Student Loan Program, Higher Vocational Education

\section{Introduction}

Tuition for vocational education in general, for higher vocational education in particular is a hot issue attracting the society's concern in the conditions that Vietnam is expanding higher vocational education scale for building higher practical technical human resources for the economic and social development. In fact, developing higher vocational education tuition rates both matching training expenses and the affordability of the learners is a complicated problem requiring reasonable solutions and strategies. During the last years, higher vocational education tuition has been increased along with GDP growth of per capita, but in fact, higher vocational education tuition rates in Vietnam is still low compared to the actual requirements. School year 2013 2014, higher vocational education tuition in Vietnam is between $2.6-6.3$ millionVND/year/student [2]. "Compared to tuition rates applied in some foreign Vocational training college in the same period as Wuhan Vocational Training Technical Institute (17.2 millionVND/year/student); Nanjing Vocational Training Technical Institute (14.3 millionVND/student/year) [1] is not difficult to recognize that higher vocational education tuition rates in Vietnam is much different while the costs of higher vocational education is basically the same. Although higher vocational education tuition fees in Vietnam today is still low compared to the actual requirements but it is beyond the affordability of learners, especially for students whose families are in difficult economic circumstance. This problem has a close relationship with the evolution of growth of per capita income and the increase in CPI in recent years in a natural manner. Basing on statistical analysis of the higher vocational education tuition issue in Vietnam during 2010 2015, this article shows intrinsic contradictions as well as the limitations of the higher vocational education tuition issue. Thence suggesting some suitable solutions to the handle the higher vocational education tuition issue in Vietnam today.

\section{Higher Vocational Education Tuition Issue in Vietnam Today}

\subsection{Changes in the Growth of Tuition}

From the Decree no. 49/2010/ND-CP of the Government of Vietnam on the tuition ceiling for higher vocational education from the school year 2010-2011 to the school year 2014-2015 shows that the higher vocational education tuition ceiling for the training fields has risen through the school years. 
Table 1. Higher vocational education tuition ceiling rateand growth in CPI during 2010-2014.

\begin{tabular}{|c|c|c|c|c|c|}
\hline Year & 2010 & 2011 & 2012 & 2013 & 2014 \\
\hline $\begin{array}{l}\text { Highest (thousand } \\
\text { VND/month/student) }\end{array}$ & 410 & 440 & 460 & 490 & 520 \\
\hline $\begin{array}{l}\text { Increase over the } \\
\text { previous year (\%) }\end{array}$ & & $7.31 \%$ & $4.5 \%$ & $6.5 \%$ & $6.1 \%$ \\
\hline $\begin{array}{l}\text { Lowest (thousand } \\
\text { VND/month/student) }\end{array}$ & 220 & 230 & 250 & 260 & 280 \\
\hline $\begin{array}{l}\text { Increase over the } \\
\text { previous year }(\%)\end{array}$ & & $4.5 \%$ & $8.7 \%$ & $4 \%$ & $7.7 \%$ \\
\hline $\begin{array}{l}\text { CPI increased over the } \\
\text { previous year }(\%)\end{array}$ & $11.75 \%$ & $18.13 \%$ & $6.81 \%$ & $6.04 \%$ & $4.09 \%$ \\
\hline
\end{tabular}

Source: Decree No. 49/2010/ND-CP and Vietnam General Statistics Office

School year $2014-2015$, higher vocational education tuition ceiling rate in Vietnam ranges from 280 thousand VND to 520 thousand VND/month/student. Compared with school year 2010 - 2011, the highest and the lowest higher vocational education tuition ceiling rate has increased from 60 thousand VND to 110 thousand VND/month/student and that the annual tuition ceiling rate increases less than $10 \%$ against the previous year. This reflects the growth in higher vocational education tuition ceiling rate slow and not commensurate with the actual requirements. First, the period 2010 - 2014, GDP growth tends to go down, but CPI increase leads to price rises and of course the cost of investment in vocational training must also increase accordingly. Second, one of the specific characters of higher vocational education is to train higher practical technical human resources meeting the enterprise's demand. Therefore, schools should invest in advanced training equipment. At the same time, apprentices spend $70 \%$ of total time of learning at workshops for vocational practice and production practice, costs for practical material, utilities, mechanical wear... is significant and it requires appropriate investment funds. Third, in the era of market economy, enterprises are applying the scientific and technical achievements to increase productivity. Employees who are qualified, skillful in operation of modern production lines are also paid reasonable salaries. Thereby, resulting in the demand of wage raise from teachers, those who are involved in training and teaching in the field of higher vocational education. From the above objective causes, especially the first and second causes, it can be seen that the growth in higher vocational education tuition ceiling rate in Vietnam in recent years is slow and low compared with the actual requirements.

\subsection{Affordability of Learners}

Affordability of learners is one of the important factors which can evaluate logicality, illogicality in setting the tuition rates of a training system.

Table 2. GDP per capita and higher vocational education tuition rates for the period of $2010-2014$.

\begin{tabular}{lllll}
\hline Year & $\mathbf{2 0 1 0}$ & $\mathbf{2 0 1 1}$ & $\mathbf{2 0 1 2}$ & $\mathbf{2 0 1 3}$ \\
\hline Per capita GDP(millionVND/year/person) & 21.66 & 26.22 & 36.84 & 41.23 \\
Per capita GDP of poor households (millionVND /year/ person) & $4.8-6.0$ & $4.8-6.0$ & $4.8-6.0$ & $4.8-6.0$ \\
Tuition ceiling rate(million VND / year/student) & $2.2-4.1$ & $2.3-4.4$ & $2.5-4.6$ \\
Tuition ceiling rate/Per capita GDP (\%) & $10.2 \%-18.9 \%$ & $8.8 \%-16.8 \%$ & $6.8 \%-12.5 \%$ & $6.3 \%-11.9 \%$ \\
\hline
\end{tabular}

Source: Decree No. 49/2010/ND-CP, Decision No. 09/2011/QD-TTg and Vietnam General Statistics Office

Higher vocational education tuition ceiling rate has increased with the growth of per capita GDP (see Table 2), and annual tuition ceiling rate accounted for $6.3 \%-18.9 \%$ of Per capita GDP. However, because excessive increase in $\mathrm{CPI}$ result in costs for pursuing higher vocational education compared to the affordability of learners. Especially for the poor households, the poor households under the Decision no. 09/2011/QD-TTg of the Government. Survey on the living expenses of Student Support Center of Van Lang University, it is showed that 2013 living expenses in Ho Chi Minh City ranges from 19.55 to 26.76 million VND/student/school year. Thus, total living expenses and tuition fees per student of higher vocational education in Ho Chi Minh City in 2013 is 26.905 million VND/student/year, accounting for $65.26 \%$ of per capita GDP in 2013 while exceeding the affordability of rather poor households, poor households as prescribed (4.98 times higher than the average income of poor households according to the regulations). Total academic cost is relatively high makes the students who are in difficult economic circumstances must take part-time job to cover academic costs or unable to pay full costs for studying, must stop school. This has significantly impacted on training efficiency as well as investment effectiveness from apprentices and their families.

\subsection{The Student Loan Program}

The student loan program is one of the student learning support policies for the students who are in difficult circumstance are studying in public universities, colleges and intermediate level training institutions through Banks of Social Policies. Since the issuance of decision on Student Credit (September 27th, 2007) so far, the Government has adjusted borrowing norms for three times. However, the current student borrowing norms are still low compared to the growth rate of CPI. Specifically in 2013, Student credit normis VND 1.1 million VND /student/month, an increase of 0.1 million VND over 2010, whereas, if the set borrowing norms bases CPI increased from 2010 to 2014, the appropriate borrowing norms is naturally higher than the borrowing normsas prescribed. In addition, to the extent of total annual academic costs (tuition fees and living expenses), lending norms can meet less than $50 \%$ of total academic costs. This shows that the Government's regime of financial support for students with difficulties including vocational education students is still limited. The limitation in academic financial support for student with the difficult economic circumstances including vocational education students that can make these objects fall in the investment risks in pursuing higher vocational education like risks in 
expectation of investment efficiency, risks of illness, risks of occupational selection... due to lack of academic costs.

\subsection{Gap in Tuition Rates}

Lower rates of tuition make someones take the advantage of higher vocational education tuition issue to exercise the purposes outside the educational scope. Used to take a permanent job in a Vocational training college in Ho Chi Minh City, the author finds that many persons pays fees for admission in Vocational training college and pay tuition fees for following vocational training courses, in fact they do not attend the training courses but their main purpose is to obtain deferment certificate of military service. Besides, a number of students in the provinces are in wealthier economic conditions, their academic costs are transferred by their families via bank, but they fail to pay the academic fees as prescribed learning, they spend the academic costs on entertainment or invest in other fields due to their poor academic sense, negative impact from the surrounding environment. These phenomena are not much, but have directly impacted on academic attitude, mentality of other students. Especially, those students are in difficult circumstance are using loans from banks for funding in apprenticeship.

\section{Some Proposals and Solutions}

To develop tuition rate both matching costs of training and learners' affordability, should take appropriate solutions and strategies generally. Basing on the existing problems of higher vocational education tuition fees in recent years, this article proposes some solutions:

\subsection{Increasing Higher Vocational Education Tuition Rates}

In the context of higher vocational education tuition rates in Vietnam today is still low and not in line with the historical costs of vocational training or otherwise is incompatible with costs of higher vocational education, increasing higher vocational education tuitionrates is a matter of necessity. To implement the plan to increase Vocational training college level tuition rates reasonably and scientifically, the Government should expand the autonomy regime to Vocational training colleges, particularly financial autonomy. Through expansion of autonomy regime, the schools will actively set up the higher vocational education tuition rates mating the actual costs of training and affordability in the economic area, the different localities. The increase in tuition rates and authorization of autonomy for Vocational training college levels in setting the tuition rateswill not only help Vocational training colleges to improve the capacity in training competitiveness, training quality but also limit the gap in higher vocational education tuitionat present.

\subsection{Innovation and Improve the Student loan Program}

Increasing higher vocational education tuition rates matching historical costs of training and costs of training will naturally put a significant economic pressure on students of Vocational training colleges with difficult economic circumstances. Therefore, Social Policy Banks should provide more loans for students with difficult circumstances in the coming. Borrowing level should meet minimum affordability of learners during the training courses. Thereby, limiting investment risks in following higher vocational education coursesfor learners. Besides, in recent years, the percentage of graduate students hardly seeking for suitable jobs, unemployment is high thus Social Policy Banks should extend the repayment mechanism, debt rescheduling for students of Vocational training college levels. Extension of repayment period, debt rescheduling will help reducing repayment pressure on students with difficult economic circumstances and help the banks reduce the risks of loan recovery.

\subsection{Social Mobilization of Financial Support for Higher Vocational Students in Difficult Circumstances}

The promulgation and implementation of student credit regime from 2007 to the present has reflected the concern and encouragement of the Party and the Government to the students who have difficulties are studying in Universities, Colleges. However, it is actually shown that the State's support budget for academic borrowing through Social Policy Banksis somewhat limited and cannot meet and settle the borrowing requirements for all students in difficult circumstance including students of Vocational training college levels. Therefore, schools should actively call for enterprises, local government, sponsors, social organizations to support academic costs for vocational students in difficult circumstances through educational promotion scholarships granted periodically. This both shows both society's concerns and supportsand reducing the economic pressure on vocational students with difficult circumstances so that they can feel secure to study and successfully graduate from schools.

\section{Conclusions}

On the basis of analyzing higher vocational education tuition issue in Viet Nam today, we can make some conclusions as follows:

- Increase in tuition rates is low and slow compared with the actual requirements.

- Increase in tuition rates is in line with GDP growth, but CPI growth makes academic costs exceed the affordability of learners in difficult circumstances.

- The Government's financial support policy for vocational students through the student loan program is limited. This can create investment risks in pursuing vocational college training courses for learners with difficult economic circumstances.

- Gap in tuition fees has affected academic attitudes, psychology of students persuing vocational training courses, though their impacts are negligible.

- For personal perspective, this article proposes three solutions to complete current tuition issue for higher vocational education in Viet Nam includes the tuition increase of higher vocational education; innovation and improvement of student credit regime and calling for 
social forces to participate in financial support for vocational students in difficult circumstances.

- Although analysis of higher vocational education tuition issue within this article is not really full and comprehensive and the suggested solutions still depend on economic growth and increasing inflation in the coming period but the article will somewhat impact on Vocational training college leveltuition issue.

\section{References}

[1] BAO Hai-qin (2008). Changes in Higher Education Tuition Policy in China. China: Tshinghua Journal of Education, Vol. 29 No 2pp. 71-76.

[2] Cao Shu-Jiang (2014). Some issues on tuition of Chinese Higher Education. China: Journal of China Higher Education Research,Vol.5 pp. 44-48.

[3] Decree No. 49/2010/ND-CP stipulating a tuition ceiling rate for higher vocational education from school year 2010-2011 to school year 2014-2015.

[4] Decision No. 09/2011 / QD-TTg of the Prime Minister promulgating standards of poor households, rather poor households in the period of 2011-2015.

[5] Decision No. 157/2007/QD-TTg of the Prime Minister on the student loan program.

[6] Decision No. 1196/QD-TTg on adjustment of lending rates to students on July 29th, 2013.

[7] General Statistics Office (2014), growth in per capita GDP and CPI increased from 2010 to 2014.

[8] Gao Guijuan, Chen Hui (2005). The Introduction of the History of Higher Education Tuition in China. China: Journal of Quijing Normal University, Vol.24No.1pp. $84-86$.

[9] Hu Maobo \& Shenhong (2008). The Debate about Higher Education Tuition Pricing and Its Enlightenments. China: Juece Cankao, pp. 16-20.

[10] JIANG Xiao - hui (2007). Research on tuition of higher education. China: Journal of Higher Education Management, Vol.1 No.4 pp. 48-51.

[11] LI Qing - hao, SHEN Hong (2005). The Changes in Higher Education Tuition in West Countries and Impications. China: Comparative Education Review. No.9 pp. 29 - 35.

[12] Li Yu - nan, Ying Qi (2009). On The Issue of Colleges Tuition. China: Journal of Hubei College of Finance and Economics, Vol.21pp. 27-29.

[13] LIN Yan - li (2007). An Economic Analysis About the Quasiprice Mechanism Attribute of the Higher Education Tuition Fee. China: Journal of Northeastern University, Vol.9 No.6pp. 506-510.

[14] Liu Minquan, YU Jian tao, Li Pengfei (2006). Tuition Fees and the Equitable Access to Higher Education in China. China: Peking University Education Review, Vol.4 No.2 pp. 47-60.
[15] MA Lu-ting (2007). Policy on tuitions and students assistance in higher education. China: Journal of Higher Education Management, Vol.1 No.2pp. 35-39.

[16] SUN Wen - bing, WANG You - e (2009). Optimization Model and Analysis for Higher Education Tuition. China: Journal of Shaoyang University, Vol.6 No.1 pp. 18-22.

[17] TIAN Wei, LILi (2009). A Bi - directional Optimization Model about the Standard of China's Higher Education Fee. China: Journal of Honghe University, Vol.7 pp. 24-30.

[18] TIAN Yan (2005). A Theoretical Research on Factors in Determining Tuition of Higer Education. China: Journal of Jiangsu University, Vol.27No.1 pp. 50-53.

[19] Van Lang University (2013). Student's living costs: How much for a month.

[20] Wu De-kun, Qu Xiao-wei (2011). China Educational Economic review 2010. China: Educational Science Publishing house.

[21] Wu De-kun, Qu Xiao-wei (2012). China Educational Economic review 2011. China: Educational Science Publishing house.

[22] WU Wei, HONG Lin (2011). A Review of the Payment Capacity of the Public for Higher Education and the Tuition Policies. China: Evaluation and Management, Vol.9 No.1 pp. $19-23$.

[23] Wu Yi-ying (2008). Introduction to Higher Education Economic. China: Guang Dong Higher Education Publishing House.

[24] Xia Zhiqiang (2005). Mechanism of Higher Education Tuition. China: Social and Economic, No.2 pp. 85-91.

[25] XU Xin-sheng, Li Ji-dan, ZHAO Kuan, XU Tao (2009). The Interaction Programming Model for Higher Education Tuition. China: Journal of Binzhou University, Vol.25 No.6 pp. 39-42.

[26] XU Guo - xing (2006). Ideologies and Practicies of Fee Policies in Higher Education. China: Education \& Economic, No 2pp. 11-25.

[27] XU Guo - xing (2004). Tuition Fees and Opportunity of Equality in Higher Education. China: Education \& Economic, No.4pp. 6-11.

[28] YU Ying (2007). An International Comparative Study of Cost Sharing In Higher Education. China: TshingHua Journal of Education, Vol.28 No.3 pp. 111-118.

[29] Yang Chengbu (2011). An Empirical Analysis of Influencing of University Tuition. China: Education Developing Research, Vol.19 pp. 8-13.

[30] Yang Yang (2010). Investigation On the Tuition Fees of Higher Education. China: Science Technology and Industry, Vol 10, 2010 pp.107-110.

[31] ZHANG JI - hua (2008). Analysis \& Suggestions of Higher Education Tuition Policy of China. China: Theory and Practice of Education, Vol.28 No.7 pp. 25-27. 